\title{
Percursos de pesquisa, caminhos de mediação* Entrevista com Mônica Raisa Schpun
}

\author{
Research Paths, Mediation Paths: \\ Interview with Mônica Raisa Schpun
}

Entrevista realizada em Paris, no dia 3 de setembro de 2020, por Caion Meneguello Natal ${ }^{\text {}}$ e Fabiana Marchettii**

Mônica Raisa Schpun nasceu em São Paulo a 18 de novembro de 1964. Diplomou-se em história pela Universidade de São Paulo (1987) e doutorou-se pela Universidade de Paris, com a tese Paulistanos \& paulistanas: rapports de genre à São Paulo dans les années vingt (1994), sob orientação de Michelle Perrot. Entre 1997 e 2002, Mônica lecionou na Universidade de Milão, junto ao Centro de estudos Donne e differenze di genere. Em 2004, começou a trabalhar no Centre de recherches sur le Brésil colonial et contemporain (CRBC), da École des hautes études em sciences sociales (EHESS), em Paris, instituição em que ela permanece até hoje e onde dirige a revista Brésil(s). Sciences humaines et sociales. Mônica dedica-se à história do gênero e da imigração, e coordena pesquisas de estudantes brasileiros que vão à Europa para desenvolver mestrados, doutorados e pós-doutorados.
Mônica Raisa Schpun was born in São Paulo on November 18, 1964. She graduated in history from the University of São Paulo (1987) and obtained her doctorate from the University of Paris, with the thesis Paulistanos \& paulistanas: rapports de genre à São Paulo dans les années vingt (1994), under the guidance of Michelle Perrot. Between 1997 and 2002, Mônica taught at the University of Milan, as a member of the research center Donne e differenze di genere. In 2004, she started working at the Centre de recherches sur le Brésil colonial et contemporain (CRBC), at the École des hautes études en sciences sociales (EHESS), in Paris, institution where she remains today and from where she directs the magazine Brésil(s). Sciences humaines et sociales. She coordinates researches from Brazilian students who go to Europe to develop masters, doctorates and post-doctorates.

\footnotetext{
* Este trabalho contou com o apoio da Fundação de Amparo à Pesquisa do Estado de São Paulo (FAPESP). Caion Meneguello Natal: processo n. 2019/16557-0; Fabiana Marchetti: processo n. 2019/20322-9.

** Universidade de São Paulo (USP), São Paulo, SP, Brasil. caionnatal@hotmail.com <https://orcid. org/0000-0003-0357-3202>

*** Universidade de São Paulo (USP), São Paulo, SP, Brasil. fabi10_marchetti@hotmail.com <https:// orcid.org/0000-0002-3229-8177>
} 


\section{Como foram sua infância e adolescência?}

Eu nasci em São Paulo, no Jardim Paulista, numa família de judeus laicizados. Meus avós eram imigrantes judeus ucranianos que chegaram a São Paulo nos anos 1920. Meus pais já tinham nascido no Brasil e se conheceram em São Paulo. Eu sou a terceira geração de uma família que não seguia os preceitos religiosos. No entanto, eu frequentava a comunidade judaica, meus pais eram sócios do Clube Hebraica e eu vivia num mundo comunitário. Quando era adolescente, eu fiz parte de movimentos juvenis judaicos, também totalmente laicos.

Quando eu entrei na USP em 1983, para cursar história, foi uma abertura para mim, porque, pela primeira vez, o mundo não era dado de antemão. A escolha das companhias se tornou mais livre, abrangente e variada. Então, me afastei da sociabilidade comunitária e virei as costas para essas raízes judaicas, nas quais eu tinha nascido, sido criada; e fui fazendo meu percurso de modo diferente. Encontrei pessoas ligadas às coisas de que eu gostava - os livros, $\mathrm{o}$ aprendizado, o estudo -, e fui fazendo outros tipos de amizades, em um universo engajado, militante e de esquerda.

A minha entrada na USP foi uma grande descoberta. Em 1986, eu terminei o bacharelado. Em 1987, a licenciatura. Já era momento de crise, em seguida viria o Collor, e eu me deparei com a dificuldade de encontrar emprego, de não saber o que fazer. Queria ser historiadora, mas era um mundo tão minúsculo... Eu tinha um emprego, mas fui mandada embora de maneira violenta. Trabalhava na Folha de S. Paulo. Desse modo, resolvi fazer pós-graduação.

\section{Você trabalhou como jornalista?}

Trabalhei como redatora. Era um emprego que eu detestava, um ambiente péssimo, mas, pela primeira vez, eu tinha um salário bom. Já estava pensando em me mudar de casa. Eu tinha saído um tempo da casa dos meus pais para morar com um namorado, mas tive que voltar por falta de dinheiro. A Folha de S. Paulo pelo menos me dava uma autonomia, mas, após a experiência de três meses, eles me mandaram embora. Ultrapassaram-se dez dias e por isso tiveram que me pagar todos os direitos. Eu estava esgotada, decidi viajar. Vim para a Europa, que eu não conhecia.

\section{Essa viagem foi a princípio turística?}

Sim, para mudar de ares. Eu recebi uma bolada de dinheiro. Falei: vou viajar. 
Aqui em Paris, conheci Michel Paty, um filósofo que dirigia uma revista de história e filosofia da ciência internacional, impressa e publicada no Brasil. Ele também participava da cátedra francesa do departamento de filosofia da USP, onde tinha muitos alunos e amigos. Quando eu o encontrei, falei que estava pensando em fazer pós-graduação e apresentei algumas questões que eu queria estudar; um tema próximo da história das mulheres, de que na época se estava começando a falar no Brasil. E ele falou: eu conheço aqui a grande referência. Ele conhecia a Michelle Perrot e me colocou em contato com ela. Falei com ela por telefone e ela disse que aceitava me orientar.

\section{O que te motivou a estudar história?}

Isso foi maravilhoso. Eu sempre estudei em escolas que, na época, eram consideradas "modernas"; aquelas experimentais, com classes pequenas, etc. Quando eu e meu irmão fomos para o colegial, meus pais falaram que iam pôr a gente em uma escola que garantisse nosso ingresso em uma universidade pública. Meu pai era engenheiro do Departamento de Estradas de Rodagem (SP), ganhava um salário esmagado pelas crises. E minha mãe era secretária. Eles puseram a gente em uma escola tradicional, o Colégio Bandeirantes, no qual eu não me adaptei de jeito nenhum. Foi aí que eu percebi um interesse pelas humanidades. No Bandeirantes, isso nem existia. Optava-se entre as ciências exatas ou biológicas. Eu escolhi as exatas. A parte da língua, da literatura, da história e da geografia era um complemento menor.

Uma menina da minha classe teve a mesma experiência. Ela não gostou do Bandeirantes e decidiu voltar para sua escola anterior, uma escola judaica (I. L. Peretz). Era uma escola que não fazia a diferença entre o "científico" e as humanidades. Eu também resolvi me mudar para essa escola. Os professores eram bons e meu professor de história era o Nicolau Sevcenko. Foi então que eu gostei demais da disciplina. Quando eu entrei na USP em 1983, o Nicolau tinha acabado de ser admitido. Tive aula com ele no segundo ano de graduação.

\section{Quando você viajou para a França, você já conhecia os estudos sobre gênero? Como você chegou a esse tema?}

Quando fiz graduação, ninguém falava nesse assunto. Depois eu soube que a Maria Odila Leite da Silva Dias já naquela época estava trabalhando com isso, mas, nos anos em que eu cursei história, não tive aulas com ela. Quando eu vim para Paris, estava sendo publicado no Brasil o primeiro livro de Michelle Perrot, uma coletânea de artigos organizada pela Maria Stella Bresciani. ${ }^{1}$ 
Eu sempre gostei do período contemporâneo. Eu fazia como ouvinte, na pós-graduação, uma matéria do professor Carlos Alberto Vesentini (19471990), que morreu de AIDS. Isso era em 1988. Quando eu voltei da Europa, fiz mais um semestre, e então eu contei para ele sobre minha estadia na França e sobre o livro de Perrot. Ele pediu para eu ler e discutir dois artigos do livro. Esse foi meu primeiro contato com a obra dela.

Quando eu cheguei a Paris em 1989, a ideia de gênero estava começando a ser discutida. A palavra era incômoda para os franceses, porque vinha dos Estados Unidos ("gender"). Eles não queriam usar a palavra americana - na França se resiste ao que é visto como importado. No Brasil, é o contrário, todo mundo devora antes de pensar. Na França, as sociólogas e as antropólogas, antes das historiadoras, já falavam em "relações sociais de sexo". Quando entrou a palavra "gênero", havia vários debates sobre isso. Naquela época, ainda se falava "história das mulheres".

\section{Como você desenvolveu o projeto de pesquisa?}

Eu cheguei a Paris para fazer um DEA (Diplôme d'Études Approfondies), que acontecia um ano antes do doutorado. No começo, ia ser um DEA que se chamava "Histoire et civilisations". Quando eu cheguei, Michelle Perrot falou: estamos abrindo um DEA novo, chamado "Sexe et société", que é interdisciplinar, com sociólogas e antropólogas. Eu fiz o primeiro ano do DEA "Sexe et société” na Paris VII, de 1989 a 1990. Cheguei em setembro de 1989. E aí estava começando toda essa discussão. Os cinco volumes de Histoire des femmes en occident foram lançados entre 1991 e 1992, e ainda se falou por muito tempo em história das mulheres. Quando se falava em gênero era preciso justificar. Alguns termos alternativos eram "relations de sexe", "rapports sociaux de sexe", etc.

O DEA substituía o nosso mestrado. Não fiz mestrado. O que eu acho, hoje, que foi um erro, porque eu vim para a França sem experiência de pesquisa. A graduação no Brasil não dava essa formação. A gente aprendia a fazer pesquisa no mestrado. Se eu tivesse feito, chegaria à França menos crua, mas eu tinha pressa e uma ideia na cabeça: sair da casa dos meus pais e voltar a estudar. Quis vir rápido. A oportunidade me parecia imperdível: eu vim, fiz o DEA, e, em setembro de 1990, entrei no doutorado. 
Michelle Perrot foi sua orientadora durante o DEA e também no doutorado. Você pode nos contar sobre as pesquisas que você desenvolveu sob orientação de Perrot?

No DEA, eu escolhi um tema francês porque eu não teria acesso aos arquivos brasileiros. Eu estudei como duas das mais importantes revistas femininas de Paris nos anos 1920 retrataram as mulheres no espaço público e no espaço privado, em imagens, ilustrações e fotografias. Uma delas era popular, com tiragem maior, Le Petit Écho de la Mode. Era um jornal, na verdade, em forma de tabloide. A outra era sofisticada, em papel brilhante, com mais fotos, a Femina. A banca do DEA gostou do meu trabalho, tive uma nota altíssima.

Em seguida, fui ao Brasil, aos arquivos, onde eu vi que poderia pesquisar outras revistas. Coletei material, trouxe microfilmes, cópias, comprei muitos livros. A partir disso, em minha tese, estudei as relações de homens e mulheres da elite no espaço público de São Paulo durante os anos 1920. Se eu tivesse tido maior visão, teria trazido as fontes já da primeira vez, para trabalhar um ano a mais em minha tese. No DEA, eu trabalhei com um tema exógeno para mim. Isso me obrigou a ler muito, o que foi bom, porque eu adquiri uma cultura sobre a história francesa, melhorei meu francês, mas eu tive um ano a menos para trabalhar meu tema.

\section{Como você vê a contribuição de Michelle Perrot para seu amadurecimento intelectual?}

Michelle Perrot era uma historiadora ativa. Ainda é. A gente a escuta o tempo todo no rádio, na televisão. Mas, na época, ela era mais. Ela dava um seminário de história das mulheres e outro que se chamava "Séminaire Foucault". Eu frequentava os dois. Perrot se aposentou quando eu estava fazendo a tese, mas, como ela era emérita, podia levar os orientandos até o final. Nosso contato era formal e distante. Discutíamos meu trabalho, em geral, uma vez por ano. Tinha que ter um texto já escrito, que eu mandava pelo correio, depois eu telefonava para ela e marcávamos um encontro para discutir o que eu havia enviado.

Apesar dessa relação formal, a gente aprendia ouvindo as aulas e lendo as coisas dela. Eu aprendi muito nos congressos, mesas-redondas, lançamentos de livros, etc., em que ela se apresentava. Quando eu estava no doutorado, foi criada a "escola doutoral" de Paris VII, que existe até hoje; são seminários mistos que reúnem muitas áreas. Michelle Perrot estava lá e eu ia a todos os 
eventos em que ela estava presente. Eu li as coisas dela também. Eram as primeiras publicações na França sobre história das mulheres.

Fazer história das mulheres era marginal na época. Lembro que, quando eu estava procurando emprego, me apresentando para concurso, a Françoise Thébaud $^{2}$ - que eu conheci bem, estava na banca de minha livre-docência falou para mim: quando você apresentar teu currículo nas candidaturas, esconda o máximo que você puder que você estudou história das mulheres. Era impossível esconder, mas acho que a Françoise deve ter sentido a dificuldade na pele, ao longo de anos de profissão. Quando eu estava decidindo com a Michelle Perrot quem iria fazer parte de minha banca de doutorado, ela falou: tem que ter um homem. Senão, ninguém vai acreditar que é um trabalho sério, que te demos o título de doutora sem ter um homem na banca. Eu me lembro que, na banca de outra aluna dela, Christine Bard, havia "o tal homem", e esse cara falou que, para ele, o feminismo não era movimento social. Isso deve ter ocorrido em 1992 ou 1993, antes de eu defender minha tese. O que significa isso? A doutoranda tinha que justificar que ela acreditava que o feminismo era um movimento social. Ou seja, era preciso explicar algo anterior àquilo que você estudava. Era um meio misógino. Hoje tem muitas historiadoras das mulheres, mas, encontrar um lugar ao sol na universidade francesa foi uma luta ferrenha. Para mim, ainda, que fazia história das mulheres no Brasil... Hoje ficou mais internacionalizado; a França mudou.

Até a geração de Michelle Perrot, não se podia utilizar, em uma tese, bibliografia que não fosse em francês. Ninguém citava bibliografia em inglês. Naquela época, elas estavam começando a ler bibliografia anglo-saxã, onde havia justamente a discussão do "gender". Primeiro, elas estavam lendo para recusar; depois, para questionar, para reagir. Estavam entrando em cena as primeiras historiadoras feministas. Eu vivi essa efervescência. E Michele Perrot era uma pessoa aberta. Ela discutia todas essas autoras. A gente falava no feminino, porque não havia autores; os homens começaram a estudar o assunto das masculinidades quando já se falava em gênero, mas isso foi após eu defender minha tese (1994). A ideia de gênero incluía estudar os homens também.

Michelle Perrot dizia algo que me faz pensar até hoje: "o homem é o geral, a mulher é a parte”. Hoje parece óbvio, mas na época não era nada óbvio. Era preciso desconstruir, mostrar a dinâmica de gênero. Havia essa coisa pesada para desconstruir, essa ideia de que o geral era o homem e a parte eram as mulheres. Tudo isso tinha relação com a antropologia. Michelle falava frequentemente da antropologia. Houve muitos debates a respeito dos cinco volumes 
de Histoire des femmes en occident. Quem eles chamavam para debater? Os homens. Senão, ninguém iria reconhecer aquela importância.

Sua formação intelectual se deu conjuntamente à formação de um campo de pesquisa, em meio a um debate incipiente sobre história das mulheres e sobre questões de gênero?

Exatamente. Coincidiu com essa efervescência de um campo que estava se construindo. Eu tinha sempre um pé no Brasil, porque, naquela época, no Brasil, começou a ser realizado o grande congresso "Seminário Internacional Fazendo Gênero", em Santa Catarina. Eu tinha esse duplo olhar, que é a vantagem de você ser imigrante. Na França, as pesquisadoras debatiam o conceito de gênero e resistiam a aceitá-lo, resistiam ao que vinha dos Estados Unidos. No Brasil, era aquela avalanche de estudos sobre gênero. Logo no começo, pouca gente sabia do que estava falando. Muita gente adotava o conceito sem ter lido as coisas. No Brasil, de certo modo, a história das mulheres foi substituída por história do gênero sem se fazer muita reflexão. Depois se fez a crítica disso. Por outro lado, o Brasil - principalmente na antropologia, na sociologia, por causa de uma relação próxima com os Estados Unidos - avançou mais que a França. Quando aqui ainda se falava em relações sociais de sexo, no Brasil, por exemplo, já se falava em interseccionalidade.

Mônica, você defendeu sua tese de doutorado em 1994. Como foi para você,, uma mulher brasileira, doutora por uma instituição francesa, procurar emprego na França? Você pode contar como construiu sua vida profissional?

Eu não fui a única. Michelle Perrot tinha muitas relações com o Brasil e recebeu muitos estudantes brasileiros, muitas meninas que estavam nesse filão de história das mulheres. Porém, a maioria voltava, e eu fiquei. E então foi uma decepção horrível. Não conseguia arranjar emprego. Eu defendi minha tese em maio de 1994; em novembro nasceu minha filha. Aí as coisas se dificultaram, porque eu estava procurando emprego e com o neném recém-nascido.

No fim de 1996, ofereceram a meu marido um bom cargo profissional em Milão. Eu não tinha emprego e estava de baixo astral. Então nós aceitamos. Em abril de 1997, fomos embora para a Itália, onde ficamos por cinco anos. Michelle Perrot me indicou a uma ex-aluna dela, que trabalhava no centro de estudos de gênero em Milão. Nesse centro, elas logo se interessaram por meu trabalho e me deram o estatuto de "visiting fellow". Eu trabalhei cinco anos lá, 
dei aula, pesquisei, frequentava as reuniões, frequentava as casas delas. $\mathrm{O}$ moral melhorou muito.

Voltamos em 2002. Comecei a procurar emprego aqui com a mesma dificuldade de antes. Eu tinha cinco anos de experiência na Itália. Para mim contava muito. Porém, para os júris de concursos na França, contava menos, porque era "só" a Itália (risos) na visão daquela época.

Eu gostava do CRBC (Centre de recherches sur le Brésil colonial et contemporain), lá na École (École des Hautes Études en Sciences Sociales, EHESS). Quando eu voltei de Milão, o historiador Jean Hébrard estava colaborando com o CRBC. Eu já o conhecia. Ele falou que seria interessante eu ministrar um seminário que se chamava, na época, "Séminaire de Centre". Era voluntário, somente para ter experiência, então elaborei um programa. Eu tinha trabalhado com o tema da imigração nos cursos que eu dava na Itália e vinha me interessando pelo assunto. Eu ainda tentava relacionar gênero e imigração. A questão emigratória é incontornável para a história italiana. Há milhares de especialistas e é um campo prestigioso.

\section{A experiência na Itália incentivou seu interesse pelo tema da imigração?}

Sim. Eu tinha feito minha tese sobre São Paulo, sobre a urbanização. Claro, a urbanização está diretamente ligada à imigração, mas, como eu estava estudando as elites, esse tema acabou sendo pano de fundo. Ele se impôs para mim quando eu estava na Itália, onde os historiadores de primeira linha trabalhavam com imigração. Na França, não era exatamente assim, mas, quando eu voltei, pensei: vou fazer um seminário sobre isso. Voltei em 2002 e comecei o "Séminaire de Centre" em 2004, meu primeiro no CRBC. Depois eu consegui um contrato. O contrato foi renovado. Enfim, era meio precário, mas eu estava me afirmando.

Então, conheci Nancy Green, grande especialista de história da imigração, professora da École. Ela me convidou para dar com ela seu seminário principal. Eu lecionei com ela durante dois ou três anos e, depois, criamos juntas um seminário sobre cinema e imigração. Eu era do comitê da revista Cahiers $d u$ Brésil Contemporain, dirigida pela Marion Aubrée, que agora está aposentada. Marion é uma grande amiga, me apoiou naquela época. Durante um período, ela compartilhou sua sala comigo. Assim, eu fui aumentando minha presença e meu trabalho na École. Os Cahiers du Brésil Contemporain deixaram de ser financiados pela Maison Sciences de l'Homme e foram substituídos por uma nova revista elaborada por mim, a Brésil(s). Sciences humaines et sociales. Com 
a criação dessa revista em 2011, entrei no CRBC. No ano seguinte, houve um concurso e fui efetivada.

No meio acadêmico francês, você sentiu alguma dificuldade por ser brasileira, considerando esse processo de afirmação profissional?

Antes de eu ir para a Itália, eu achava difícil, porque era como se a gente sempre tivesse que se justificar por estudar o Brasil. Principalmente na história. Imagino que, na antropologia, não, porque é um laboratório importante. Mas, para a história, que, das ciências humanas, é a mais prestigiosa na França, que é a base da República laica e jacobina; a história é a ciência humana e social por excelência... Agora mudou, mas, na época, se você não fazia história da França, sobrava pouco espaço. No máximo, eles estavam expandindo o olhar para o Magrebe, as ex-colônias.

Nos cinco anos em que morei na Itália, intensificaram-se as trocas culturais e intelectuais. A França estava se abrindo para a Europa e percebendo que, se ela não se abrisse, ficaria para trás. Quando eu voltei, a gente não se embaraçava em dizer que estudava um tema fora da história francesa. Mesmo assim era difícil, porque as vagas para concurso eram cada vez menos numerosas e havia cada vez mais candidatos. Vagas que incluíssem a América Latina e o Brasil eram raras. Contudo, no CRBC e no laboratório Mondes Américains - que se construiu pouco depois (2006) - eu estava num meio em que todo mundo trabalhava com a América Latina ou com o Brasil.

Hoje você desenvolve pesquisa a respeito da imigração de judeus e japoneses ao Brasil durante o governo de Getúlio Vargas (1930-1945). Por que você resolveu se aprofundar no estudo desses grupos?

Comecei a buscar objetos interessantes sobre imigração que não deixassem em segundo plano a bagagem que eu tinha sobre gênero. Preparando meus cursos, encontrei algumas entradas. Em 2008, comemorou-se o centenário da imigração japonesa no Brasil. Houve muitas festividades e publicações. No seminário que eu estava dando, resolvi fazer um semestre sobre a imigração japonesa, porque era um tema que não se conhecia aqui, um grupo migratório que não estava presente na sociedade francesa. Para preparar o curso, eu li em um livro que os imigrantes japoneses no Brasil estavam fazendo uma operação plástica que se chamava "ocidentalização dos olhos". Eu fiquei super interessada, porque isso tinha relação com gênero, com corporalidade, com corpo, questões todas que eu tinha estudado. 
Naquele momento, eu havia concluído um pós-doutorado em Milão sobre Carlota Pereira de Queirós, a primeira deputada mulher no Brasil, eleita em 1932, que assinou a constituição de 1934. Eu tive acesso aos arquivos privados de Carlota, com os descendentes dela. Por anos eu a pesquisei. Quando voltei da Itália, eu estava trabalhando nesse tema. Publiquei diversos artigos, mas nunca cheguei a fazer um livro sobre Carlota. Parei porque eu fiz essa reconversão para a questão migratória. E também porque, cada vez que me convidavam para conferência ou congresso, começou a ficar uma etiqueta forte, marcada. Biografia é algo complicado. As pessoas perguntavam se eu não tinha nada além da Carlota. Eu achava, e ainda acho, que Carlota abria uma porção de entradas diferentes. Ela foi uma das primeiras médicas do Brasil, além de ter sido a primeira deputada federal. Havia várias coisas para se trabalhar. Acho que os artigos que eu fiz não se repetem. Mas tinha sempre o nome dela. No entanto, eu trazia toda essa bagagem de gênero que não queria largar.

O trabalho sobre Carlota tinha a ver com a questão corporal, por se tratar de uma mulher ocupando os espaços masculinos. Ela se tornou uma pessoa visível, ocupava um espaço importante no mundo da política e na medicina. Falava-se muito da "beleza" ou da "feiura" de Carlota. Quando eu li sobre a "ocidentalização dos olhos" dos japoneses, eu me interessei por conta da questão corporal. Fui ao Brasil, realizei entrevistas, observação nas clínicas de cirurgia plástica, entrevistei os cirurgiões e, ao final, publiquei dois artigos. Para escrevê-los, eu me dediquei a uma literatura sobre história da imigração japonesa, mergulhei nesse assunto. A pesquisa ficou interessante, eu poderia continuar, mas era difícil não morando no Brasil.

Enquanto eu estava fazendo esse trabalho, parte dos meus cursos era sobre imigração judaica. Eu me interessei por dois aspectos. Um era o Lasar Segall, pintor que eu sempre adorei. Segall viajou muito, imigrou muitas vezes durante a vida. Eu fiz um trabalho sobre os deslocamentos migratórios dele, sua vida e pintura. Ao estudá-lo, vi uma menção ao nome de Aracy de Carvalho como uma "justa” brasileira. O Brasil tem dois "justos" entre as nações, sendo que uma é mulher, coisa rara. Na época em que eu fiz a pesquisa, entre os "justos" havia cerca de 30 pessoas do mundo diplomático. Desses 30, só uma mulher, a nossa brasileira Aracy de Carvalho. Assim como o tema da "ocidentalização dos olhos", isso também me interessou, pois, novamente, me ligava à minha bagagem de gênero, de história das mulheres.

Ela foi a segunda mulher de João Guimarães Rosa e, por coincidência, uma amiga estava assumindo a curadoria do fundo Guimarães Rosa no IEB (Instituto de Estudos Brasileiros da Universidade de São Paulo) naquele mo- 
mento. Eu escrevi para ela perguntando sobre o assunto. Ela me disse que os arquivos da Dona Aracy tinham acabado de chegar ao IEB para ficarem juntos ao fundo do Guimarães. Eu resolvi fazer uma incursão nesse material, que estava sendo organizado. Ainda havia muitas restrições e foi uma coisa que se arrastou um pouco até que eles liberassem todo o acesso ao fundo. Eu entrei em contato com a família de Aracy, que liberou a correspondência. Escrevi um ou dois primeiros artigos. Em 2008, foi o centenário de nascimento de Aracy, quando a imprensa começou a publicar de novo artigos sobre ela. Eliane Brum, então repórter da revista Época, foi ao IEB e soube de minha pesquisa. Ela entrou em contato comigo, dizendo que queria me entrevistar. Conversamos e ela publicou uma matéria.

Uma cineasta do Rio de Janeiro, Mariza Leão, leu a matéria e decidiu fazer um filme sobre a pesquisa. Procurou a Eliane para obter meu contato e me ligou. Ela falou: quero comprar o direito do seu livro. Eu respondi que não tinha livro nenhum. Então, a Mariza me apresentou à Civilização Brasileira, um selo do grupo Record, e disse: você faz esse livro e depois eu faço o filme. Eles me adiantaram um dinheiro relativo aos direitos autorais que me permitiu fazer a pesquisa nos arquivos da Alemanha. Foi quando a pesquisa deslanchou. Eu fui para a Alemanha, fui ao Arquivo Nacional (Rio de Janeiro), fiz uma pesquisa grande.

A cineasta nunca fez o filme por questões de direitos autorais. Eu vendi os direitos para a Rede Globo que deverá fazer uma minissérie. Para mim, o importante é que o livro foi publicado.

\section{O livro foi publicado em 2011 e se intitula Justa. Quem foi Aracy de Carvalho?}

O livro se intitula Justa: Aracy de Carvalho e o resgate de judeus. Aracy era uma moça de classe média, cujo pai era comerciante português e tinha sido dono de um cassino no Guarujá. A mãe, alemã, era dona de casa. Eles moravam em Perdizes (bairro de São Paulo). Ela tinha uma tia, irmã da mãe, que morava na periferia de Hamburgo. Aracy era casada com um descendente de família alemã.

Em 1934, aos 26 anos, em uma São Paulo provinciana, Aracy decide se desquitar, e, com um menino de cinco anos, vai embora para a Alemanha, morar na casa da tia. Ela chega a uma Alemanha nazificada. Naquele ano, já havia ocorrido o boicote ao comércio judaico; logo depois vieram as primeiras leis drásticas antissemitas, as leis de Nuremberg. Ainda havia crise, os nazistas estavam combatendo a recessão. Tanto que ela acaba se tornando um peso 
para a tia. Então, ela consegue emprego no consulado do Brasil em Hamburgo em 1936. Em 1938, João Guimarães Rosa assume o cargo de cônsul adjunto. Assim eles se conhecem e logo começam a namorar.

Quando ela entra no consulado, as coisas já estão difíceis para os judeus. Essa configuração pessoal de vida, que ela está resolvendo com o emprego, acaba colocando-a numa posição chave dentro dessa nova configuração alemã. Seu posto é de chefe do setor de passaportes. Ela administra e submete todas as demandas de vistos que serão concedidas pelo cônsul. Ela tem contato direto com os solicitantes e começa a facilitar a ida de judeus para o Brasil, aproveitando as brechas do regime varguista.

Eu segui esse itinerário imigratório e sua vida em um Brasil provinciano, de onde ela escapa por causa do desquite. Isso foi ligando o tema do gênero com o eixo migratório. A migração faz você mudar de mundos. Na Alemanha, o fato de ela ser mãe desquitada não era obstáculo, mas ela entrava em uma conjuntura política distinta. Por um desses acasos da história, ela ocupou uma posição chave. Desse modo, localizei uma constelação de imigrantes que foram de Hamburgo para o Brasil com o auxílio de Aracy. Eu segui o percurso migratório deles nos arquivos alemães e no Arquivo Nacional. Na verdade, a Aracy é o pivô do livro, mas, como os arquivos são nominativos, eu pude seguir o percurso migratório desse grupo.

\section{Você pode explicar o que é o título de "justa"? Por que uma pessoa recebe esse título?}

"Justos" são pessoas não judias que se arriscavam para salvar judeus durante a guerra. A seleção passa por um denominado "Tribunal do bem". A pessoa deve ser apresentada ao júri desse tribunal por pessoas que foram salvas por ela. Não pode ser testemunha indireta. E precisa haver pelo menos duas testemunhas através de um dossiê. Há comissões em Israel que julgam o pedido e concedem o título. Existem em torno de 23 mil justos no mundo. A grande maioria, na Europa. Nas Américas todas há seis justos: três americanos, uma chilena e dois brasileiros. Isso não significa que todas as pessoas que ajudaram são reconhecidas.

\section{A entrada de Aracy em suas pesquisas acaba representando um retorno à sua origem judaica?}

Sim, é verdade. É sempre difícil falar de si mesmo. Mas, houve um retorno de alguma maneira, primeiro um afastamento e depois um movimento 
circular até que eu pudesse me encontrar com esse tema. Antes dela, eu trabalhei com uma perspectiva biográfica a partir de Carlota de Queiroz. Depois, veio a questão migratória, primeiro os japoneses, os judeus, então, Segall, que era artista... Ao final, Aracy, uma mulher que salvou judeus. É trilhar um percurso que vai longe e volta.

Participei, por muitos anos, de um grupo internacional que estudava a relação entre história e literatura. Em uma das reuniões, um professor me disse que eu deveria estudar um tema judaico, ao qual ele se referia. Então fica essa coisa, judeu faz história de judeu. $\mathrm{Na}$ época eu encarei super mal. O que eu quero dizer: eu tinha me afastado disso há tempos, mas ainda era uma questão sensível pra mim. Quando eu fui fazer A Justa, já não era mais. Eu acho que foi preciso um distanciamento para ter feito esse livro com serenidade. Os italianos, por exemplo, se descobriram como italianos quando chegaram ao Brasil ou aos EUA, ou seja, a partir do olhar do outro. Com os judeus também tem isso, mas minha família de judeus ucranianos não tinha nada a ver com os judeus alemães que eu estudava. Contudo, de certo modo, eu estava sensível à questão judaica, ao salvamento de judeus na Segunda Guerra.

Quando eu emigrei para a França, percebi que ser judia no Brasil tinha um significado diferente. Aqui foi território da Ocupação, o Brasil viu tudo isso de longe e, na verdade, se você pensar nas identidades múltiplas de uma pessoa, a parte judaica, que eu havia colocado de lado, era a única parte, entre ser brasileira e ser judia, que não dependia da territorialidade. Portanto, ficou mais sensível para mim depois que eu emigrei do que antes. Escrevi Justa após minha imigração. Ela se tornou minha livre-docência e foi a conclusão de um percurso, a reunião de vários temas de pesquisa, principalmente gênero e imigração.

\section{Como você mantém o vínculo com as instituições e colegas brasileiros? Qual a importância desse vínculo para você e para sua atuação profissional?}

Quando eu comecei a trabalhar aqui, na época da tese, eu via muitos colegas estrangeiros irem para os seus países de origem, especialmente a América Latina, só pra trabalhar nos arquivos. Hoje não é assim, mas na época era, e eu já achava isso inconcebível. Eu sempre mantive uma ligação forte com meus amigos e colegas do Brasil e acho que, sem isso, não daria para "segurar a peteca”. É vital você sempre dialogar, discutir, para saber se aquilo que você faz está no bom caminho.

O meu primeiro vínculo institucional no Brasil foi com o Núcleo de Estudos de Gênero Pagu (UNICAMP), logo que eu concluí o doutorado. Foi por 
meio de Stella Bresciani, que conhecia Michelle Perrot e com quem eu me encontrei várias vezes ao longo da tese. Quando fui, pela primeira vez, ao Pagu, lembro-me de Adriana Piscitelli e de Mariza Corrêa. Mariza foi uma coisa maravilhosa para mim, uma intelectual fascinante, de conhecimento, abertura de espírito, de simplicidade e sofisticação. Durante os anos em que eu fui do Pagu, ela se interessava pelas minhas coisas, e eu era nada! Ela trocava e-mails comigo, lia minhas coisas e conversava sobre o meu trabalho (na época eu pesquisava a Carlota). Essa interlocução tão preciosa, que, para quem está no Brasil acontece nos corredores, comigo tinha de ser ritualizada, formalizada e à distância. A pessoa tem que dedicar mais tempo a você, e Mariza fazia isso. Stella também. Ela foi "a brasileira" que veio para minha banca. E, nos anos do Pagu isso foi essencial para mim. Depois, o grupo foi se transformando. No começo havia muitas historiadoras, mas o grupo se encaminhou para as discussões de sexualidade, que não eram bem o meu tema.

Continuei na UNICAMP ainda por anos, especialmente no Centro de Estudos da Cidade, dirigido pela Stella Bresciani. Recentemente, comecei a fazer contatos com a USP. Eles se deram a partir de um projeto internacional francês sobre jardins históricos, para o qual fui convidada por duas colegas daqui - uma historiadora e outra arquiteta. Era importante ter alguém do Brasil, país prioritário nesse programa de internacionalização.

Não sou paisagista e o tema estava longe das minhas pesquisas. Eu tampouco poderia dar uma guinada tão grande em minha carreira. Propus a elas um trabalho sobre o Jardim da Luz, que é cercado por bairros de imigração e me permitia fazer uma história social. Contatei Paulo Garcez, do Museu Paulista, que eu já conhecia por amigos comuns e que trabalhava com isso; além de ele ser uma pessoa da USP, que pôde ficar como o responsável local do projeto. Convidei outras pessoas, duas da UNICAMP, Stella e Josianne Cesaroli, e uma especialista em Burle Marx, Vera Siqueira, da UERJ.

Fiquei com o comando do projeto aqui na França e cada um de nós escolheu um jardim: Vera escolheu o jardim privado de Burle Marx, Stella escolheu o Ibirapuera, Josiane escolheu a Praça da República, Paulo escolheu o Jardim do Museu Paulista e eu, o Jardim da Luz. Nós fizemos vários congressos, dois no Brasil, e agora vamos fazer um livro. Assim meus contatos com a USP foram se aquecendo. Paulo me aproximou do pessoal da FAU, onde ele é professor da pós-graduação, e eles começaram a se interessar pelos meus temas, porque a questão da imigração não faz parte do leque de disciplinas que eles oferecem. Eu fiz uma estadia na FAU com financiamento da FAPESP. No final de 2016, surgiu um edital para uma bolsa de 30 meses que tinha meu 
perfil (foi Paulo quem me mandou). Eu pensei que seria uma boa oportunidade de ficar mais tempo, concorri e deu certo. Assim eu me aproximei da USP e passei 19 meses indo e vindo.

\section{Você também recebe muitos estudantes e pesquisadores. Como se dá essa circulação e qual a importância dessas relações para você?}

É vital, é o interessante de estar no CRBC. Eu tentei passar em diversos concursos e, se tivesse passado em algum deles, provavelmente eu não teria essas relações, pois estaria num departamento de história contemporânea. Talvez, com muita sorte, eu poderia dar um curso de mestrado sobre questões latino-americanas, mas nunca daria um curso sobre o Brasil e os brasileiros não teriam interesse de passar lá. Hoje, o CRBC é um dos grandes centros europeus de estudos sobre o Brasil, ao lado do King's College.

Muitas relações que se iniciam no Brasil continuam aqui. Paulo Garcez, por exemplo, já passou seis meses comigo; Ana Lana, que me recebeu na FAU, esteve aqui; o pessoal da UNICAMP vinha muito. Sendo assim, minhas redes estão sempre nos dois sentidos. E há a revista, também, que é um veículo através do qual os autores se deslocam. Eu criei um seminário para que eles realizem conferências. Essa agenda é importante, uma ferramenta da nossa visibilidade.

Os alunos são uma maravilha. Se você pensar em números absolutos, não tem muita gente que estuda história do Brasil na França; talvez antropologia tenha mais. É preciso que eles saibam português e eles não o aprendem nos liceus. A gente tem que recrutar pessoas que vêm do Brasil, ou que estudaram português na faculdade. Contudo, eu tenho esse fluxo de bolsas sanduíches que eu adoro, que se renova sempre. Chegou um grupo grande no ano passado. Para esse novo ano escolar, achei que seria um vazio, mas estão aparecendo candidaturas de novo. Esse intercâmbio é vivo.

\section{É possível mobilizar atividades e espaços de trabalho que tornem esses vín- culos duradouros?}

O problema é que não há dinheiro. A École tem um programa para financiar a vinda de convidados, mas eu não tenho acesso, pois o meu vínculo é de pesquisadora. Os professores podem convidar um colega por ano, para ministrar quatro conferências, em média. Agora, os colegas que vêm com financiamento brasileiro, normalmente, ficam mais de um mês. É raro virem para ficar só um mês, então, não faz tanta falta para eu manter esse fluxo. Eu recebo muita gente. Eu consigo oferecer espaço para conferência, seminários 
e dar visibilidade, valorizar essa estadia. Faço o possível para que as pessoas aproveitem a estadia e retornem. Algumas retornam.

\section{Você atribui um sentido para o seu papel de mediação entre a França e o Brasil?}

Sim. A casa está sempre aberta e eu tentei expandir essas relações a partir da ABRE. As pessoas que passam por aqui têm a possibilidade de encontrar pesquisadores de outros países.

O Congresso da ABRE em Paris (2019) cresceu sem que a gente esperasse. Significa que havia uma demanda à qual estávamos respondendo, mesmo sem sabermos. Temos que ver agora se isso se sustenta; vamos anunciar o próximo congresso que vai ocorrer em Praga. Eu tenho a impressão de que o calendário do "pré-Covid" e do "pós-Covid" nos beneficiou. Nós fizemos o Congresso antes de tudo ser paralisado e acredito que, para o evento seguinte, as coisas já vão estar melhores. Assim, nos encontraremos em Praga depois de tantos cancelamentos.

Espero também que o sucesso de Paris não tenha sido efêmero e que as nossas redes tenham durabilidade. Eu vou mobilizar minhas redes e propor, àqueles que fizeram mesas-redondas, que repitam as atividades no formato de pequenos grupos de trabalho, nos quais as pessoas se reencontrem a cada dois anos. Vamos ver se as pessoas vão conseguir viajar, porque, no meio disso, veio a crise financeira.

\section{A ABRE tenta articular pesquisadores entre Europa, França e Brasil. No seu caso, como você se envolveu com essa entidade?}

Começou com meu envolvimento na BRASA, a Brazilian Studies Association, a associação de estudos brasilianistas nos EUA. Ela surgiu como um braço da LASA, a Latin American Studies Association, mas ficou independente há uns 15 anos. Uma associação mais estável e antiga que a nossa.

Eu passei a ir cada vez mais aos Estados Unidos e fiz muitos congressos com James Green, um amigo próximo, inclusive dois que faziam esse triângulo França - Brasil - EUA. Fizemos um na Casa de Rui Barbosa e outro na USP. Na BRASA de 2014, em Londres, havia muitos europeus e foi a oportunidade de se pensar em formar algo como a BRASA na Europa.

Eles fizeram então o Congresso no King's College, quando surgiu essa ideia e Green a estava incentivando. Marcaram uma reunião para o último dia, e ele me dizia o tempo todo: você tem que estar na reunião. Havia gente de 
vários países, e eu não quis me envolver na época, mesmo que eles levantassem a questão sobre um representante em Paris. Assim, constituiu-se um grupo piloto para fazer um mapeamento no sentido de se criar uma associação europeia de brasilianistas.

Em seguida, eles começaram a debater o estatuto da organização. Nesse momento, passei a ajudar e integrei o comitê científico do I Congresso que ocorreu em Leiden, na Holanda, organizado por Mariane Wiesebron - evento modesto, com 70 pessoas. Foi ali que se elegeu a primeira diretoria, e eu decidi tomar parte. Consultei o CRBC e a École - porque eles me disseram que, se eu me tornasse a vice-presidente, o próximo congresso seria organizado por mim, então eu tinha que saber se era possível. Eles me disseram que sim e eu me envolvi. Eu fui vice-presidente entre maio de 2017 e setembro de 2019.

A ABRE é interessante. Por estatuto, a diretoria tem um representante de cada país. Desde o Congresso de Paris nós somos sete, então eu propus que nós votássemos um representante dos doutorandos. Nós somos variados, mas toma bastante tempo. Até setembro do ano que vem eu estou nisso, mas estou me cansando.

Agora, estou em pleno processo de avaliação do prêmio da Melhor Tese Europeia sobre o Brasil. Esse foi um projeto meu. Sempre acreditei que nós deveríamos aproximar os doutorados europeus. No Congresso de Paris, fizemos um investimento financeiro para favorecê-los: $1 / 3$ dos inscritos eram doutorandos. Ano passado tivemos 19 inscritos para o prêmio, e esse ano, 28.

\section{Hoje, quantas instituições e pesquisadores estão envolvidos na ABRE?}

$\mathrm{Na}$ diretoria somos sete. A diretora de comunicação é de Portugal, a tesoureira é de Oxford, na Inglaterra, a secretária é de Berlim, a vice-presidente é de Praga, eu estou em Paris e o diretor para outras atividades é de Zurique. A representante dos doutorandos, que é a única que não precisa responder a essa exigência de não se repetir o país, é de Lausanne, na Suíça.

No congresso, tivemos mais de 600 adesões e cerca de 530 inscritos de 23 países, incluindo pessoas de outros lugares, como os EUA e o Canadá. Pouco menos da metade dos inscritos eram brasileiros.

\section{É possível identificar um perfil dos estudos brasilianistas na Europa através das teses e dos congressos?}

Não. É impossível, é muito variado. Há alguns temas muito presentes, como, por exemplo, a Amazônia: indígenas, meio ambiente, ecologia, minera- 
ção, agrobusiness, questões climáticas. Agora, também há trabalhos sobre favelas e pobreza urbana, educação, toda a parte artística. Porém, mapear é difícil.

Em termos cronológicos, há uma coincidência entre o surgimento da ABRE e o início de um período de crise política no Brasil. Você vê uma relação ou impactos desse processo na formação da entidade?

Foi realmente coincidência, não houve nada planejado. Achamos, no começo, que seria uma coincidência infeliz, que o congresso iria por água abaixo com a crise que veio. Primeiro, o impeachment, depois a campanha presidencial até a eleição de Bolsonaro. Temer, que agora parece fichinha, naquele momento já era uma catástrofe. Ao final, aconteceu o contrário no que diz respeito a ABRE, pois o Congresso de 2019 ganhou um significado e se tornou um espaço de encontro, debate e troca de ideias maior do que se ele tivesse sido realizado em tempos normais. Tornou-se um fórum importante.

No entanto, é complicado fazer uma relação de causa e efeito que pode ser mecânica. As coisas ocorreram próximas e não se tem o devido distanciamento para avaliarmos. Talvez, a demanda já existisse sem esse contexto horripilante e o congresso apenas tenha dado vazão a ela. Mas o momento reforçava essa necessidade de termos um fórum de debate. Todos queriam falar sobre o Brasil, e os europeus queriam ouvir os brasileiros. Nós fizemos uma atividade do sábado, solicitada e financiada pela École, para convidarmos os brasileiros a pensarmos, juntos, em formas de colaboração. Tentamos fazer do congresso um espaço para respondermos positivamente a esse contexto. Mostrar que o brasilianismo poderia ser um sustentáculo internacional interessante.

Mônica, você vê a ABRE e suas outras atividades como formas de intervenção e colaboração com a sociedade brasileira, para além do sentido profissional que elas têm para você?

Acho que sim. Acredito que meu papel como mediadora contribui. É importante essa experiência de internacionalização para os estudantes, para os pós-doutorandos e mesmo para os professores. Oferecemos infraestrutura e fazemos tudo para valorizar a vinda deles, desde a disponibilidade de uma sala até a organização de eventos para que sejam ouvidos e tenham uma possibilidade de retorno.

Muitas pessoas reconhecem. Por exemplo, recebi Bruno Gomide nesse último período e ele me falou: Mônica, eu já estive em vários lugares, mas nunca tive um retorno como aqui. E outras pessoas já me disseram que foram 
para diferentes universidades europeias e não foram igualmente acolhidas, isto é, não tiveram o mesmo espaço de interlocução que o nosso. É um retorno bacana, porque a gente se esforça para que seja assim.

Nesse contexto político, você acha que o olhar estrangeiro sobre o Brasil, especialmente do europeu, adquire um novo significado? Em que medida ele é importante?

Acho que sempre é. James Green, por exemplo, estudou como as campanhas por direitos humanos puderam exercer alguma forma de pressão contra os militares durante a ditadura. Quando olhamos a partir de certa distância, notamos como tudo que trata da imagem do Brasil no exterior - a exemplo desses apoios e pressões internacionais, atuais ou mais antigos - cumpre um papel. Essa mobilização não é inútil e demonstra que as fronteiras não isolam, quer dizer, demonstra que o Brasil tem esse espelho voltado para fora. Se aqui temos um olhar e uma mobilização sobre o que está acontecendo no país, é porque temos laços fortes, de mão dupla. Eu acho que sim, é importante, não só para o Brasil, mas para nós, também. Ainda mais para mim, eu que tenho a dupla pertença... também é legal.

Após tantos anos na França, como você vê a sua posição de pesquisadora em relação à sua identidade e aos vínculos que você tem nos dois países?

A gente é o que é, não é mesmo? Quando eu comecei a procurar emprego aqui, me dei conta de que não sabia fazer muita coisa. Se eu não fosse historiadora, o que eu poderia ser? Na época, por exemplo, se eu quisesse trabalhar em um museu, diferente do Brasil, aqui eu teria que fazer a École du Louvre, teria de começar do zero, ir para a graduação, como se eu fosse me tornar dentista! Teria que voltar tudo para trás. E eu pensava comigo: Já emigrei, foi um esforço tão grande. Hoje, parece banal, mas, naquela época, não era. Hoje é uma coisa assentada e serena, mas durante anos não foi. O tempo faz seu trabalho. Eu vim como historiadora e essa é uma profissão sacrificada, se você não gosta muito... Não foi fácil para mim!

A posteriori, como estamos fazendo aqui, construímos coerências que não necessariamente existem. Esse fio que a gente está construindo é uma elaboração posterior. Para fazer a livre-docência, escrevi um memorial de fôlego. Fui obrigada a refletir sobre o meu percurso, é um trabalho pesado. No momento em que você está se deslocando, você tem uma visão parcial do que está acontecendo - quais as possibilidades, os obstáculos - e o acaso também 
age. São conjuntos complexos de realidade. E a gente não pode ter tudo, não é? Algumas coisas dão certo, outras não!

\section{Como a Mônica historiadora vê o Brasil hoje?}

O Brasil está numa situação terrível. Qualquer palavra é pouca, e sempre piora. Agora, eu entrei nessa campanha contra o projeto de lei de João Dória ${ }^{3}$. Ele, que, atualmente, é o grande adversário político de Bolsonaro e está colocando a USP, a UNESP, a UNICAMP e a FAPESP na lata do lixo. Os colegas de lá pediram que os colegas internacionais gravassem pequenos vídeos contrários ao projeto.

Eu passei os últimos dias coletando em minhas redes quem pudesse gravar uma mensagem. Fizemos também um seminário de onze semanas para apoiarmos a Casa Rui Barbosa, que está sendo destruída, e agora vamos fazer uma campanha com outros colegas para defendermos a Cinemateca Brasileira.

Graças à FAPESP, acreditávamos que as universidades paulistas iriam sobreviver ao desgaste das outras universidades, as quais dependem da CAPES e do $\mathrm{CNPq}$, que foram demolidos. Dória está destruindo tudo também, inclusive a FAPESP, um patrimônio único. É triste. O que podemos fazer é pouco, ainda mais de longe, mas eu faço tudo o que posso. Todo mundo aqui está meio paralisado, porque, no laboratório Mondes Américains, todo mundo trabalha, se não com o Brasil, com os outros países, fazendo, portanto, seu campo no exterior. Esse ano ninguém fez, porque as fronteiras estavam fechadas.

Creio que o Brasil precisa de ajuda internacional. Não está fácil. E com a pandemia, tudo ficou pior.

\section{REFERÊNCIAS}

DÓRIA, João. Projeto de lei no 529/2020: Estabelece medidas voltadas ao ajuste fiscal e ao equilíbrio das contas públicas e dá providências correlatas. 2020. Disponível em: https://www.al.sp.gov.br/propositura/?id=1000332222. Acesso em: 28 jan. 2021.

DUBY, Georges; PERROT, Michelle. Sous la direction de SCHMITT-PANTEL, Pauline. Histoire des femmes en Occident. Vol. I. L’Antiquité. Paris: Plon, 1991.

DUBY, Georges; PERROT, Michelle. Sous la direction de KLAPISCH-ZUBER, Christiane. Histoire des femmes en occident. Vol. II. Le moyen âge. Paris: Plon, 1991.

DUBY, Georges; PERROT, Michelle. Sous la direction de ZEMON DAVIS, Natalie; FARGE, Arlette. Histoire des femmes en Occident. Vol. III. XVI ${ }^{e}$-XVIII ${ }^{e}$ siecle. Paris: Plon, 1991. 
DUBY, Georges; PERROT, Michelle. Sous la direction de FRAISSE, Geneviève; PERROT, Michelle. Histoire des femmes en Occident. Vol. IV. Le XIX siècle. Paris, Plon, 1991.

DUBY, Georges; PERROT, Michelle. Sous la direction de THEBAUD, Françoise. Histoire des femmes en Occident. Vol. V. Le XX siècle. Paris: Plon, 1991-1992.

PERROT, Michelle. Os excluídos da história: operários, mulheres e prisioneiros. Rio de Janeiro: Paz \& Terra, 1988.

SCHPUN, Mônica Raisa. Justa. Aracy de Carvalho e o resgate dos judeus: trocando a Alemanha nazista pelo Brasil. Rio de Janeiro: Civilização Brasileira, 2011.

SCHPUN, Mônica Raisa. Paulistanos \& paulistanas: rapports de genre à São Paulo dans les années vingt. 2 Vol. Tese (Doutorado em História) - Paris Diderot (Paris 7), Université de Paris. Paris, 1994. 737 p.

THÉBAUD FRANÇOISE. Thébaud Françoise. Disponível em: https://www.mnemosyne.asso.fr/mnemosyne/mnemosyne/annuaire/thebaud-francoise/. Acesso em: 28 jan. 2021.

\section{NOTAS}

${ }^{1}$ Trata-se do livro Os excluídos da história: operários, mulheres e prisioneiros, publicado pela editora Paz \& Terra em 1988.

${ }^{2}$ Françoise Thébaud é uma historiadora francesa, professora emérita de História Contemporânea na Universidade de Avignon e pesquisadora associada ao Instituto de Estudos de Gênero da Universidade de Genebra. Ela se dedica à história das mulheres no século XX e foi diretora da revista CLIO, Histoire, Femmes et Sociétés entre 1995 e 2012 (Thébaud Françoise).

${ }^{3}$ Trata-se do Projeto de Lei 529/2020, publicado em 13 de agosto de 2020, que prevê cortes significativos nos recursos destinados à Fundação de Amparo à Pesquisa do Estado de São Paulo (FAPESP) e às universidades públicas estaduais de São Paulo (UNESP, USP e UNICAMP). Além de tais retiradas, o referido PL estabelece também a extinção de mais de dez autarquias e fundações, entre as quais o Parque Zoológico de São Paulo e a Empresa Metropolitana de Transportes Urbanos de São Paulo (EMTU/SP). Ver: Dória, 2020. 